\title{
Die verband tussen genade en werke in 1QS se reddingsbegrip ${ }^{1}$
}

J W Semmelink

\section{ABSTRACT}

The relationship between faith and works in the soteriology of 1QS

An analysis was made of $1 Q S$ to construct its view on grace and works in salvation. The author contends that Qumran makes much of works and that E P Sanders understated this element. Salvation according to $1 Q S$ can best be described by the modern term "synergism".

In die Qumrangeskrifte word genade en redding soms nou met mekaar verbind, soos in 1QS 11:13-14: "Deur sy barmhartigheid het Hy my naby gebring, en deur sy genade bring Hy my geregtigheid". Sulke ooreenkomste met temas by Paulus in die Nuwe Testament kan 'n mens laat wonder in watter mate daar ' $n$ band tussen die reddingsleer van Paulus en dié van Qumran is².

'n Studie van redding in Qumran is van belang vir die Nuwe Testament omdat dit vra of Paulus se gebruik van God se geregtigheid reeds in die pre-Christelike Judaïsme gewortel is. Indien wel, bevraagteken so 'n gevolgtrekking die tradisionele verstaan van Joodse geregtigheid, waarop 'n enorme hoeveelheid Nuwe-Testamentiese navorsing rus.

Hierdie bevraagtekening is juis deur E P Sanders gedoen. Sanders verstaan die Joodse wetsgeregtigheid binne 'n genadekonteks: "Obedience to the commandments was not thought of as earning salvation, which came rather by God's grace..."3.

A B du Toit ${ }^{4}$ het hierop reageer dat Sanders die genade-aspek in Judaïsme te skerp aksentueer. Die behoefte aan hernude Qumran ondersoek ten opsigte van bogenoemde probleme word verskerp deur die gebrekkige ondersoek tot op hede en deur die nuwe tekste wat deur Eisenman \& Wise ${ }^{5}$ vrygestel is. 'n Hele nuwe ondersoekveld is hiermee oopgestel.

Met hierdie artikel word so 'n ambisieuse taak egter nie nagestreef nie. $1 \mathrm{QS}$ word hier slegs vir die voorkoms van terme rakende redding ondersoek. 
Met $\mathrm{Kuhn}^{6}$ se konkordansie is vasgestel waar temas rakende redding in $1 \mathrm{QS}$ voorkom ${ }^{7}$. Die ter sake perikope in $1 \mathrm{QS}$ is ondersoek om vas te stel wat redding beteken en watter assosiasies daaraan geheg word. Die subjek, objek en medium van redding is geïdentifiseer. Laastens is die inligting gesistematiseer tot 'n logiese samehang.

\section{2}

\section{SAMEVATTING VAN DIE ONDERSOEK}

By die deurgaan van woorde in 1 QS wat met redding verband kan hou, moes die geldigheid van 'n woord geverifieer word, soos "geregtigheid" (משפט) wat juridiese konnotasies kan hê. Met behulp van 'n konkordansie is die verspreiding van die woorde binne die teks (Grafiek 1) grafies voorgestel.

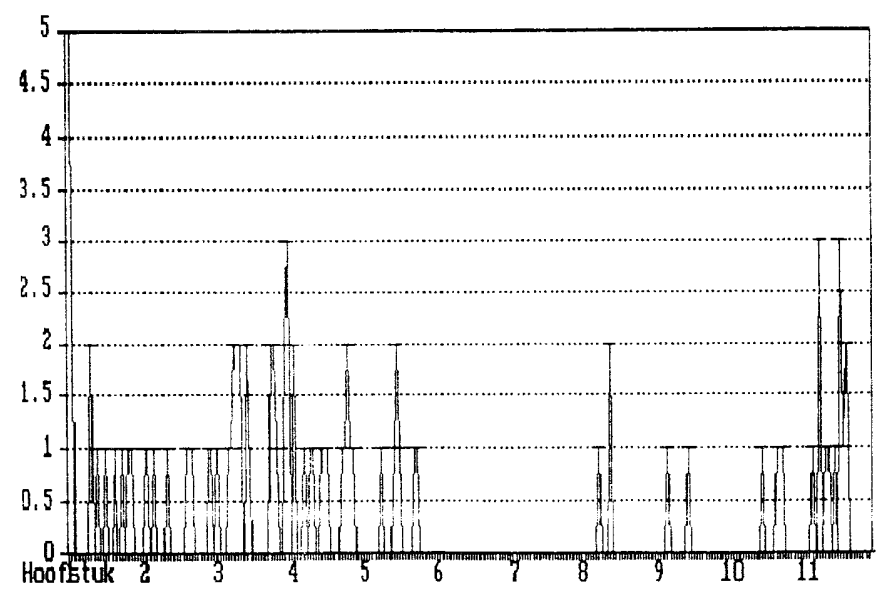

Grafiek 1 Die verspreiding van reddingsgedagtes in 1 QS

Die horisontale as stel die reëls en kolomme in $1 \mathrm{QS}$ voor. Die vertikale as stel die aantal woorde per reël voor wat vir die ondersoek geïdentifiseer is.

Die volgende perikope is vir die ondersoek afgegrens: 3:14-4:26 en 11:12-5 het die hoogste voorkoms van reddingsterme bevat. 1:1-3:12; 
5:1-20; 8:1-12 en 9:8-11 is ook vir hierdie doel geïdentifiseer. Hierdie perikope is verder ondersoek om vas te stel op watter wyse redding in die betrokke perikope weergegee word.

Die onderstaande tabel gee 'n opsomming van hierdie ondersoek en toon aan hoe redding in die betrokke perikope op verskillende wyses verstaan word.

\begin{tabular}{|c|c|c|c|c|c|}
\hline Teks: & Subjek & $\begin{array}{l}\text { Objek en sy } \\
\text { kwalifikasies }\end{array}$ & Waarvan & $\begin{array}{l}\text { Middel vir } \\
\text { redding }\end{array}$ & Gevolg \\
\hline 1:1-1I & God & Gemeentelede & - & $\begin{array}{l}\text { Gesindheid van } \\
\text { gehoorsaamheid } \\
\text { aan die wet }\end{array}$ & - \\
\hline $\begin{array}{l}1: 18 b- \\
2: 18\end{array}$ & God & $\begin{array}{l}\text { Die wat toetree } \\
\text { tot die verbond }\end{array}$ & Sonde & $\begin{array}{l}\text { Berou en beroep } \\
\text { op God se } \\
\text { geregtigheid }\end{array}$ & $\begin{array}{l}\text { Bewaar van } \\
\text { kwaad, kennis, } \\
\text { lewensinsig, } \\
\text { ewige vrede }\end{array}$ \\
\hline $2: 25-3: 11$ & $\begin{array}{l}\text { Gemeenskap } \\
(=\text { heilige } \\
\text { gees })\end{array}$ & $\begin{array}{l}\text { Die wat die wet } \\
\text { perfek onderhou }\end{array}$ & Sonde & $\begin{array}{l}\text { Opname in die } \\
\text { verbond = } \\
\text { toegang tot } \\
\text { kultiese } \\
\text { reinigingsrites }\end{array}$ & $\begin{array}{l}\text { Versoen voor } \\
\text { God }\end{array}$ \\
\hline $3: 13-4: 26$ & God & $\begin{array}{l}\text { Diegene wat in } \\
\text { die goeie gees } \\
\text { wandel }\end{array}$ & Oordeel & - & $\begin{array}{l}\text { Heil: materieel } \\
\text { en geestelik }\end{array}$ \\
\hline $5: 1-20$ & $\begin{array}{l}\text { God } \\
\text { Gemeenskap } \\
\text { Priesters }\end{array}$ & $\begin{array}{l}\text { Die wat geheime } \\
\text { kennis het } \\
\text { Die wat ywer vir } \\
\text { heiligheid }\end{array}$ & & & \\
\hline $8: 1-12$ & Gemeenskap & Land & & Dade en lyding & - \\
\hline 11:2-11 & God & Gemeentelid & & $\begin{array}{l}\text { God se } \\
\text { geregtigheid }\end{array}$ & $\begin{array}{l}\text { Lid van die } \\
\text { gemeenskap } \\
\text { Kennis van die } \\
\text { wet }\end{array}$ \\
\hline 11:11-15 & God & Gemeentelid & Sonde & $\begin{array}{l}\text { Gods } \\
\text { geregtigheid } \\
\text { (= genade) }\end{array}$ & Doel $=$ lof \\
\hline
\end{tabular}

In die tabel word genade en werke naas mekaar gehandhaaf. Die objek van redding word telkens afgegrens met sekere kwalifikasies, soos dat hulle gemeentelede moes wees of werke moes doen. Ook word genade naas die 
wet gehandhaaf. God se geregtigheid en sy genade word as sinonieme behandel. Die perikope word vervolgens vlugtig bespreek.

\section{1:1-11}

Redding het hier God as subjek en word beperk tot een objek, naamlik die gemeenskap. Wetsonderhouding speel inderdaad 'n rol in die middel tot redding 8 . In 1:1,2 moet die leraar onderrig gee in die doen van die wet en goeie werke. Reëls $4 b-11$ brei inhoudelik op die eerste uit deur sekere voorskrifte te noem: om weg te bly van die kwaad, om goed te doen, waarheid, reg en geregtigheid op aarde te bevorder. Die dokument sit dus van die begin af uiteen dat die gemeenskap bestaan om reg te doen en aan God gehoorsaam te wees.

'n Reeks infinitiewe, wat elk 'n verdere onderrigsitem spesifiseer, bind die hele perikoop onder 1:1a. Dit lyk nie of hierdie perikoop bedoel is om as 'n reeks wette gelees te word nie (Wernberg-Møller' beskou dit as 'n "golden rule"), maar dit gaan om tekens van gehoorsaamheid aan God se wil (vgl 1:2-3). Met ander woorde, redding hang nie soseer saam met die stiptelike uitvoer van gebooie nie, maar eerder met 'n gesindheid waarmee die nuweling toetree.

1:7-11 toon dat daar in die streng uitverkiesingsiening van Qumran ruimte vir ' $n$ bepaalde keuse van die mens is. Slegs diegene wat vrywillig is, kan toetree tot die verbond.

\section{1:18b-2:18}

Hierdie perikoop behels 'n liturgie vir die verbondsfees. Die verbond is jaarliks hernu $(2: 19 \mathrm{v})$, en terselftertyd is nuwe lede toegelaat $(1: 16)$. In die vier dele $(1: 18-20,1: 21-2: 1 ; 2: 2-10 ; 2: 11-12)$ praat die priesters, Leviete en die volk beurtelings ${ }^{10}$. a) Die priesters en Leviete begin die ritus as hulle "die God van reddingsdade prys en al die werke van sy trou". b) In 1:21-2:1 noem die priesters God se magtige dade en sy ontferming oor Israel. Die Leviete noem Israel se sondes en die gemeenskap doen skuldbelydenis (1:21-2:10). Sondebelydenis lei tot 'n erkenning van God se geregtigheid en 'n terugkeer na God se genade'1. Die verbond waartoe hulle toetree, is nie net een van gehoorsaamheid nie, maar ook een van berou, 'n terugkeer na die wet van Moses. c) Op die skuldbelydenis volg 'n priesterlike seën oor die verbondslede en die Leviete vervloek almal buite die gemeenskap (2:2-10). Hier lê 'n sterk reddingsmotief. Die verbondslede het hulle skuld bely in die vorige deel en die seën is 'n aankondiging dat die verhouding met God weer in orde is. Heil hang dus saam met berou en die strewe om volkome voor God te wandel (2:2). d) 
Verbondslede (2:11-12) wat met geheime sondes wil volhard, word by die oordeel ingesluit.

Redding behels dat God die subjek is, wat redding bied aan diegene wat tot die verbond toetree. Hulle word gered van sonde (waaroor hulle berou doen), en die medium vir hulle redding is die gesindheid van berou (terugkeer na die wet) en 'n beroep op God se geregtigheid. Die gevolg is seën: bewaring van die kwaad, kennis, of lewensinsig, en "ewige vrede". Die mense van die lot van Belial word in teenstelling hiermee, volgens hulle werke veroordeel $(2: 4 b-9)$.

\section{2:25-3:12}

In dié perikoop is die gemeenskap die subjek van redding. Omdat diegene wat nie tot die verbond wil toetree nie, van die gemeenskap $(2: 26)$ en van redding (3:4) uitgesluit word, is die gemeenskap die enigste verlostes. Mense buite die gemeenskap is afgesny van middele tot genade. Mens kan sê: Extra communitatem nulla salus.

In $6 b$ is die gemeenskap die gees van die "waaragtige raad van God" wat die versoening bring. Die Persoon nie, maar word met die gemeenskap self 12 in verband gebring. Met ander woorde, $6 \mathrm{~b}$ verwys na die gees van die gemeenskap as die goeie gees wat God uitverkies het. Die gemeenskap is dus die subjek van kultiese versoeningshandelinge en reinigingsrites (6-9).

Wat die wyse van redding betref, bied die bondeling se wetsgetrouheid toegang tot die gemeenskap. Dit is die voorwaarde om reinigingswater te ontvang. Indien hy hom nederig aan die wet onderwerp (8b) sal hy deur (lamed agens) besprinkeling (9) gered word, maar diegene wat hulle verhard, sal nie (3-5) gered word nie. Gehoorsaamheid is meer as 'n gemoedelike instemming; dit behels die plig om "perfek (volkome) te wandel in al Gods weë... en nie na links of na regs af te wyk nie en om nie een van sy gebooie te oortree nie" $(3: 10-11)$. Eers dan $(3: 11 b-12)$ sal hy aanvaarbaar voor God wees.

Uit 3:1,2 blyk dat daar 'n noue verband tussen kennis en wet bestaan. Die kennis wat bondelinge in die gemeenskap inbring, word aangevul met verdere onderrig. Die wet is van besondere belang omdat diegene wat dit verag, nie die versoeningsrites in die gemeenskap mag ontvang nie. Dit staan so sterk dat 'n mens kan sê dat gehoorsame wetsonderhouding 'n voorwaarde vir opname in die verbond is.

\section{3:13-4:26}

Hierdie groter perikoop word ter wille van die bespreking in kleiner eenhede verdeel. 
3:13-15a: Die belang van die eerste woorde lê in die Gattungsaanduiding.

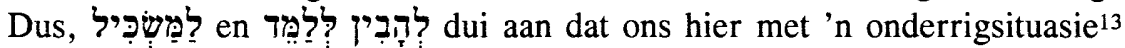
te doen het. Die leer van die twee geeste is die raamwerk waarbinne die gemeenskap se denke funksioneer, en rondom hierdie raam word die regulasies van 1 QS gebou.

3:15-19: Twee geeste regeer in die mens en verdeel die mensdom sodoende in twee kampe: die kinders van die lig en die kinders van die duisternis. Dit is ' $n$ fatalistiese predestinasieleer waarvan die strakheid na vore kom in terme soos "voor hulle bestaan", "sonder dat iets kan verander", en "soos vir hulle bepaal".

Die funksie van die geeste in die reddingsgedagte is dat God voor alle eeue 'n raamwerk van goed en kwaad (binne of buite die mens) opgestel het. Die mens wandel in een van hierdie raamwerke omdat God dit so beskik het. Om te wandel in een van die raamwerke beteken dat die mens se optrede kenmerkend van die een of die ander domein sal wees, soos in die volgende perikope blyk.

Twee interpretasies bestaan rondom die twee geeste. Een moontlikheid ${ }^{14}$ is dat die geeste twee eksterne magsfere vorm waarbinne die mens kan funksioneer. 'n Ander moontlikheid is dat die twee geeste inherent aan die mens as 'n psigologiese stryd tussen goed en kwaad funksioneer.

3:19-4:1: Die vraag of die twee geeste inherent of ekstern aan die mens is word deur 3:20v geraak. Vorste wat oor die verskillende domeine heers, word genoem. Dit kan dui op eksterne domeine. Die vors van lig sou dan waarskynlik 'n engel (Uriël) wees of die Ou-Testamentiese Engel van die Here. Die vors van duisternis word met Belial geassosieer. Elke vors het 'n deel van die mensdom in sy mag oor wie hy heers (20) en die werke van die mense in sy domein word gekenmerk deur "lig" of "duisternis" $(20,21 a)$. Ook God se liefde of haat word aan die domeine gekoppel (3:26$4: 1$ ).

Tog reken baie navorsers op grond van 4:23 dat die twee geeste eerder inherent aan die mens is. Dat Qumran self die geeste soms as inherente kwaliteite gesien het, blyk uit 4Q186(1)II (die "horoskope") waarin die ster waaronder mens gebore is die hoeveelheid bepaal wat 'n individu aan een van die twee geeste deel het. Navorsers kies gewoonlik vir òf eksterne òf inherente geeste, maar Deasley ${ }^{15}$ bevraagteken die onderliggende voorveronderstelling dat die interne en eksterne interpre- 
tasies onversoenbaar is. Moontlik het die outeur van 1QS geen spanning tussen die twee aangevoel nie. Waarskynlik is die twee geeste inherent én ekstern aan die mens gesien, sonder enige spanning.

Redding behels dat "lig" en "duisternis" retoriese terme is. Die hoorders assosieer met die groep waarin die kinders van geregtigheid beweeg, omdat hier 'n implisiete beloning verwag word en hulle dissosieer van die groep van die duisternis, omdat hier 'n implisiete straf te wagte kan wees. Hierdie implikasies word sterker gestel deur God se assosiasie en dissosiasie met die groepe in 3:26-4:1. Die een haat Hy en die ander het Hy lief.

Dit is duidelik dat redding in hierdie hele leerstuk oor die twee geeste afhang daarvan of die mens in die regte "gees" is en elke "gees" deur sy eie werke gekenmerk word. Die gemeenskap vorm dus die kring waarbinne redding moontlik is.

Uit 3:22 is af te lei dat geen enkele mens ontsnap aan die invloed van die engel van duisternis nie. Dit is nie net versoeking ('n bedreiging van die redding) wat deur die bose tot stand kom nie, maar ook al die rampe en plae. Die mens bly gewikkel in 'n stryd teen die bose wat aanhou duur tot die finale oordeel, wanneer die bose vernietig word. 'n Verskil bestaan egter tussen 3:20 en 3:22b. Die kwalifiserende woord כוֹ ("al"), word verskillend geplaas by die kinders van die lig en die duisternis, sodat die vors van die duisternis alle heerskappy kry oor die kinders van die duisternis - daar is niks goeds in hulle nie. Maar hy kry ook soms heerskappy oor die kinders van die lig. Die Qumranleer hou rekening daarmee dat die mens steeds sondig is, en dat selfs diegene wat in die reddingskring staan, nok kan sondig. Hierdie sonde word dan toegeskryf aan die maghebber van die ander kring, wat die "kinders van die lig" probeer verlei. "One finds then, a hopeless situation for the damned, and an ambiguous, though hopeful, situation for God's elect..."16.

4:2-8: Die raamwerk van die twee geeste wat in die vorige perikoop geskets is, word in hierdie perikoop in diepte bespreek. Hierdie perikoop en die volgende een vorm saam beskrywings van die eienskappe van die twee geeste, en in beide word slegs die werke van die twee geeste beskryf.

Vanaf $6 \mathrm{~b}$ word ' $\mathrm{n}$ beloning geskets vir diegene wat wandel in (הולְכיבָם) die kenmerke van die "gees van waarheid". Om te wandel het hier in besonder te make met die regte optrede. In $6 \mathrm{~b}-8$ kom 'n mengsel van konkrete en transendente heil na vore. Materieel word vrede, 'n vrugbare nageslag, 'n lang lewe en vrede beloof. Terme soos "ewig", "kroon" en "lig" dui op transendente heil. 
Dit is nie duidelik bewys dat werke as sodanig beloon word nie, maar in die lewensuitkyk of geloofsisteem van die gemeenskap het werke beslis ' $n$ rol in die reddingskema gehad. In Sanders se terme geformuleer: in die "pattern of religion" kry werke iewers tussen die beginpunt en eindpunt ook 'n plek.

4:9-14: In sy parallel met die voorafgaande perikoop hang die reddingsgedagte hier saam met dissosiasie. Die leser of hoorder distansieer hom van hierdie tipe optrede en vrees die straf wat daarop volg. Redding behels om nie op te tree soos die mense van hierdie magsfeer nie. Contra Sanders moet ons opmerk dat straf hier slegs in samehang met werke genoem word. Dit verskil heeltemal van die sondelys in Romeine 1, waar opstand

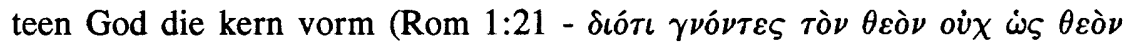
$\dot{\varepsilon} \delta o ́ \xi \alpha \sigma \alpha \nu)$.

Die heil wat in die vorige perikoop aangekondig is, kontrasteer met straf in hierdie perikoop. Die twee perikope kom daarin ooreen dat heil en straf op sowel materiële as geestelike vlak aangekondig word. Soms is die terme transendent soos "vuur", "jammerlike rou" en "lewe sonder end" (4:12-13). Soms lyk dit na 'n gerealiseerde eskatologie as die skrywer praat van 'n groot nageslag, ewigdurende vreugde, oorvloed aan plae, "tye van hulle geslagte", "sonder dat een oorbly of oorleef".

4:15-26: "Sy dit groot of klein" (4:16) het op die individu betrekking. Elke individu het 'n groter of kleiner aandeel aan die twee eksterne geeste ${ }^{17}$. "Groot" of "klein" sou die eie aard van elke persoon verklaar, dat mense beter en slegter optree. Dit kan ook verwys na range in die gemeenskap, soos in 1 QS 2:23.

4:23b dui egter weer sterk daarop dat die twee geeste inherent aan die mens self is. Inherente geeste sou kon verklaar waarom 'n reinigingshandeling in 20-22 nodig is. Die teorie dat die twee geeste spanningloos naas mekaar as intern en ekstern aan die mens beskryf word, word gehandhaaf. Die Qumranlid het homself nie as sondeloos voor God gereken nie. Hulle wat tot die magsfeer van die lig behoort, moes steeds 'n "gees van waarheid" soos reinigingswater oor hulle gesprinkel kry om gereinig te word van oorblywende onreg. Daar is egter baie spanning in hulle heilstoesegginge, want hede en eindtyd word vermeng. Hier word byvoorbeeld 'n eskatologiese reiniging aan hulle toegesê sodat hulle die opregte mag onderrig (22) - 'n deurbreking van die hede.

Die eskatologiese heilshandelinge word beskryf aan die hand van 'n reinigingshandeling wat klink na 'n geestesdoop. Die ongeregtigheid van 
die mens word sodoende gereinig en dan is daar net een gees wat verder voortbestaan.

In 25c-26 word lig gewerp op die rede waarom God iemand sou red, naamlik deur vooruitkennis. Hy ken (die loon/aard van) hulle werke deur alle ewige tye.

\section{5:1-20}

Hierdie perikoop staan onder die opskrif "En dit is die reëlings vir die manne van die gemeenskap wat hulle gewillig toon om weg te keer van alle boosheid en vas te hou aan al sy bevele volgens sy wil" (5:1). Die volgende word van hulle verwag: afsondering, ondergeskiktheid aan die priesters, sekere werke, besnydenis van die "voorhuid van begeerte en styfheid van nek" ('n uitspraak teen koppigheid). Die gemeenskap doen versoening vir "die in Aaron".

Die gemeenskap is die subjek van versoening. Wernberg-Møller ${ }^{18}$ en Garnet ${ }^{19}$ het bevind dat כפר in die Damaskus dokument (CD) altyd God as subjek het. Hier egter is die gemeenskap die subjek. Vergelyk ook 8:6 en 3:6v.

Die wyse waarop redding geskied is deur etiese integriteit ${ }^{20}$. Toetrede tot die gemeenskap is 'n toetrede tot die verbond (8). Met die verbondsluiting neem die lid 'n bindende eed om "met sy hele hart en sy hele siel terug te keer (שוֹ) na die wet van Moses" (8b,9). Die Pauliniese bekering ('n eenmalige gebeure) ontbreek: Jaarliks vind 'n verbondhernuwingsfees plaas waar hierdie toetrede opnuut herhaal word. 12-20 spreek 'n skerp oordeel uit oor diegene wat nie tot die verbond toetree nie. Geen lid mag ook steun op nietige (הֶבל) werke nie (18). Dit lyk of hier in die woordjie "steun" iets van verdienste gelees kan word.

Kennis, openbaring en wet word nou verbind. Die geheime kennis wat die gemeenskap moet hê, is die kennis van God se wil, soos dit in die tora en ander wette uitgedruk word. Hierdie kennis stel die mens in staat om tot die verbond toe te tree, naamlik om aan te sluit by die Qumran-

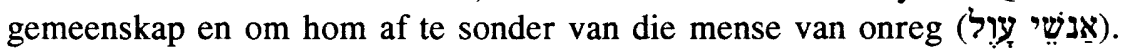
Sodoende kry die wet 'n besondere plek in die geheel van hulle denksisteem. So sterk staan die wet dat La Sor ${ }^{21}$ dié perikoop selfs as verteenwoordigend van die menslike verantwoordelikheid beskou.

\section{8:1-12}

Soos in 2:25-3:11 en 5:1-20 is die subjek van versoening nie God nie. Die gemeente doen versoening as korporatiewe agent van God ${ }^{22}$. 'n Raad van vyftien persone word aangestel en hulle taak is om versoening te doen vir 
sonde $(4,6)$. Daar bestaan twyfel of die versoenende werk slegs aan die raad van vyftien toegeskryf moet word. Die "hulle" in 8:2 verwys dan terug na die gemeenskap en nie na die raad van vyftien nie sodat versoening by die gemeenskap as kneg van die Here (na analogie van Jesaja) lê. Die perikoop "bears evidence that the Essenes considered their own organization ["church'] to be the eschatological and corporate Servant of the Lord with certain soteriological functions" 23 .

Versoening word in 8:6,10 uitgebrei om die land as objek in te sluit. Versoening geskied deur (4) "practice of justice and by suffering the sorrows of affliction" 24 . Die "waarheid" (nl die wet) word as maatstaf gestel. Die vyftien moes 'n perfekte kennis van die wet hê (1) en hulle moes met almal omgaan volgens die standaarde (4) "van die waarheid en die reëling van die tyd".

\section{9:8-11}

Die woord "messias" staan hier in die meervoud en dit word nie direk in verhouding tot redding gebruik nie. Sommige vertalings het die meervoud as skryffout verklaar en deur die yod te skrap die woord tot 'n enkelvoud geëmendeer. Dit is egter onverantwoord om die lectio difficilior van die meervoud so in 'n enkelvoud te verander.

Daar word van die gemeenskap verwag om volhardend die voorskrifte te onderhou tot die "profete en messiasse van Aaron en Israel" sal kom. Drie heilsgestaltes word verwag25: 1) die nuwe profetiese wetgewer; 2) die messias van Aaron, 'n nuwe hoëpriester uit Levi; en 3) die messias van Israel, 'n nuwe koning vir Israel. Die messiasse is hier hoogstens 'n teken van die aanbreek van die heilstyd, sonder enige reddende funksie.

\section{1:1-5}

Die gedagte van redding uit God se genade staan hier so sterk dat Burrows $^{26}$ dit aan Romeine 3:20 en Galasiërs 2:16 koppel. Die bidder beroep hom wel op regverdiging sola gratia, maar "dem sola gratia entspricht also nicht ein sola fidei..." soos Lohse ${ }^{27}$ dit stel, nie. In 11:2-3, 5 b, en 12-15 word sola gratia besonder sterk gestel. Die vraag is egter: Wat is hierdie "geregtigheid van God" in 3 en 5? Oor wie is God genadig en oor wie nie?

In 2-3 plaas die bidder sy vertroue op God se "geregtigheid" vir die uitwissing van sonde, en 'n "volkome weg". 'n Redegewende 'כִ in 3b dui aan waarom God se handeling as "geregtigheid" beskou word, en dit ontvou in 3b-8: Uit die "fontein van sy kennis" het God 'n lig vrygestel, 
naamlik 'n geheime kennis (6) wat God aan die bidder openbaar het. Hierdie kennis (7b-8) word aan diegene wat God uitverkies het, gegee as 'n ewige besitting.

God se geregtigheid (צדקה) word hier op 'n gelade wyse gebruik. In Qumran is God die bidder se צדקה, צדקה in in in derwyl Ou Testament 'n eienskap van die Godsvolk moes wees: onskuldig in die reg, opregtheid, en om reg te doen ${ }^{28}$ - die hoogste waarde in die lewe ${ }^{29}$. By 1 QS is dit aan God verbind $(3 a, 5 b, 14)$. Dit is nie bloot 'n juridiese oordeel oor die mens nie, maar 'n goddelike magswerk wat die mens aan die heilstoestand aandeel gee.

Die bidder beskryf in 9-10 sy eie onwaardigheid om heil te ontvang. Hy voel hom so verdorwe dat hy hom eerder in die geselskap van wurms tuisvoel. In 9b gebruik hy בשר (vlees), ook 'n Pauliniese woord. Die mens is in soverre hy vlees is, sy eie kneg, wat nie anders kan nie as om te sondig. בשר vervul dus die rol van 'n mag wat die mens meesleur of van 'n noodlot ${ }^{30}$ eerder as individuele sonde.

In die hoogtepunt, 10-15, is God se genade groter as die menslike swakheid. Dit is interessant dat die determinisme van 11:11 tog as 'n genadige versekering ervaar word wat die oortredinge te bowe gaan.

Soos in 3:1-11 en 5:1-20 is kennis en wet besonder nou verbind ${ }^{31}$. Dat God aan die bidder "kennis" gegee het, bied aan hom 'n versekering dat hy uitverkies is. Hierdie uitverkiesing staan so vas in God se raadsplan dat menslike oortredings dit nie kan laat wankel nie.

Die plek van genade in die loflied kan dan ook beter begryp word. Die bidder plaas in 2-3 sy vertroue op God se geregtigheid vir redding. Hierdie geregtigheid impliseer dat God aan die bidder 'n geheime kennis met die wet as inhoud gegee het. Die kennis het gelei tot die bidder se opname in die gemeenskap waar hy redding en God se genade ervaar. Die bidder voel hom meer tuis in die geselskap van wurms (10) omdat hy maar 'n sondige mens is (9b). En tog voel hy hom oorweldig daardeur dat God hom genadig was en hom uitverkies het. In hierdie opsig is dit dus geen probleem om te praat van genade nie. Maar dan is dit 'n gepredestineerde genade. "Alles wat is, word deur sy plan vasgestel" (11:11).

Dit is ook belangrik om daarop te let dat hierdie genade nie deur die doen van goeie werke verdien word nie. So 'n afleiding is totaal onbillik teenoor hierdie loflied. Inteendeel, die bidder voel hom juis hier so sondig dat hy besonder naby aan Paulus kom. Die bidder voel hom nie net behorende tot die gemeenskap van sondige vlees en wurms (9-10) nie, hy struikel self ook "in die ongeregtigheid van die vlees". Dan is God sy geregtigheid (12). 
Die Gattung van hierdie perikoop ('n loflied) verklaar die afwesigheid van werke. "This is devotional literature, and man always tends to be more humble in the presence of the Deity" ${ }^{32}$.

Die bidder kan steeds vertrou dat God se genade groter is as sy oortredinge en dus sy sonde sal vergewe (12) sonder dat hy dit werklik verdien. In hierdie opsig word genade en regverdigheid byvoorbeeld in 12 en ook in 14 as uitruilbare terme gebruik.

\subsection{Woordgebruik}

Uit die voorafgaande ondersoek is die wyse waarop die volgende woorde binne die perikope gebruik word, uitgelig:

\section{Die gebruik van כפר}

Hierdie term kom besonder baie voor en in teenstelling met die volgende term כשר i besonder ryk aan betekenisinhoud. Die woord is verteenwoordig in die meeste van die perikope hierbo genoem, en verder kom 'n variasie ook voor. 3:4 en 2:8 is redelik algemeen: "Mag God jou nie vergewe deur jou sonde te versoen nie". 3:6 bind versoening aan die gees van die raad van God, wat uit die eksegese geblyk het die gemeenskap te wees. Ook in 5:6 en 8:6 doen die gemeenskap versoening.

3:8 koppel versoening aan 'n gees van nederigheid en opregtheid. Deur sekere kwalifikasies, soos wetsonderhouding, sal die verbondslede in 3:11 aanneemlik wees voor God deur bevredigende versoeningsrites. God bring versoening in 11:14 deur sy "uitnemende goedheid". In 8:6,10 word die versoening uitgebrei om die hele land in te sluit.

\section{Die gebruik van yי}

Teenoor hierdie ryk inhoud is Leviete prys in die aanhef van die verbondsluiting die "God van reddingsdade". In 10:17 en 11:12 is dit die sanger van die loflied wat God prys "vir sy redding". Waarom Hy gered het en wat die inhoud van die redding is, word nie direk aan die woord verbind nie. Dit is meer 'n algemene woord en interessant genoeg staan al drie gebruike in 1QS binne 'n konteks van lof.

\section{Die gebruik van שוּ}

Daar word van bekering gepraat in 1QS, maar dit het 'n unieke inhoud: Dit behels dat die bekeerling nie meer verkeerde dinge doen nie en dat hy hom verbind aan die wet van Moses. Bekering is dus eties en nie soos in Christelike konteks 'n terugkeer na God nie. 
3:1 en 3 gaan om oordeel oor diegene wat die wet nie hou nie. Hulle staan nie ernstig met betrekking tot hulle bekering nie en verontreiniging kleef aan so 'n bekering.

5:1 lui: "Dit is die reël vir die lede van die gemeenskap wat hulle vrywillig verbind het om hulle te bekeer van alle kwaad en te hou aan al sy (God se) gebooie volgens sy wil". In 5:8 moet so iemand 'n "bindende eed neem om met sy hele hart en siel terug te keer na elke bepaling van die wet van Moses".

Die gebruik van טהר

Nie net kultiese gebruike (bv 3:5) kom voor nie. In 3:7, 4:21 word die gemeentelede deur 'n "heilige gees" en in 3:8 deur "onderworpenheid aan al sy gebooie" gereinig (טהר).

Uit die analise van die perikope is 'n sistematiese uiteensetting saamgestel van die Qumran reddingsgedagte.

\subsection{Die Qumran reddingsleer is 'n ontwikkeling uit die Ou Testamentiese reddingsleer}

In Gerhard von Rad se bespreking van die dekaloog word soortgelyke elemente rakende soteriologie beklemtoon as hier: uitverkiesing, verbond, kennis en die wet. Die dekaloog is beskou as "a guarantee of her (Israel's) election, for in it Jahweh had shown his people a way and a statute" 33 . Die wet is nie verstaan as 'n absolute morele wet nie. Israel "rather recognised it as a revelation vouchsafed to her at a particular moment in her history, through which she was offered the saving gift of life" ${ }^{34}$. Die Qumrangemeenskap het op hulle eie wyse die leer van die Ou Testament weer aktueel gemaak en na hulle eie situasie deurgetrek. Die tradisie is herinterpreteer en nuut verwerk.

\subsection{Predestinasie tot communitatis salus en communitatis repudiatio}

Die wyse waarop 3:13-4:26 gestruktureerd is, word deur Davies ${ }^{35}$ min of meer soos volg uiteengesit: 


\section{VAN GOD KOM:}

alles wat is en sal wees

Niks kan verander nie

Hy skep die mens om oor die wêreld te heers

Hy stel twee geeste vas waarbinne hy kan wandel

3:19-4:1 Die Gees van Waarheid Die Gees van Ongeregtigheid

Oorsprong in fontein van lig Oorsprong in fontein van duisternis

Vors van die lig heers oor Vors van duisternis heers oor

Kinders van geregtigheid Kinders van die duisternis

Wandel in weë van die lig Wandel in weë van die duisternis

Hy verlei kinders van die lig

Hulle oortredings val in sy domein

God help kinders van die lig

Op dié twee geeste het God elke werk gegrond: (3:25)

God het die gees lief God haat die gees

Hy het 'n behae in sy weë God haat sy weë

4:2-8 Die weë van die Lig 4:9-13 Die werke van die Duisternis

Verlig mens se hart Traag in geregtigheid

Geregtigheid

Ontsag vir Gods gebooie

Nederig, geduld

Barmhartigheid

Oneindige goedheid...

Boosheid

Leuens

Trots, hoogmoed

Valsheid, bedrog

Wreedheid...

\section{BELONING}

Genesing

Vrede

Lang lewe...

Eervolle kleed

\section{VERGELDING}

Oorvloed plae

Ewige verderf

Smaad

Vuur...

Daar is stryd tussen die geeste

Werke van onreg is 'n gruwel Werke van waarheid is 'n gruwel

$$
\text { GOD STEL 'N EINDE AAN DIE KWAAD }
$$

Seën

Straf

Redding in Qumran vind plaas binne die konteks van 'n dubbele predestinasie waarin God die lot van die kinders van die lig en van die duisternis 
vooraf bepaal $(3: 25-4: 1 ; 4: 16)$. God het twee "geeste" of lotsbeskikkings gepredestineer waarin 'n mens kan wandel. Die gees van die lig ontvang heil, die gees (lot) van die duisternis ontvang die verderf. Diegene buite die gemeenskap is dus van middele tot genade uitgesluit. Dus: Extra communitatem nulla salus $(2: 25-3: 11 ; 8: 1-12)$.

Dit bepaal die antropologie sodanig dat die mense nie net in twee klasse van goed en sleg, kinders van die lig en die duisternis ingedeel word nie, maar die karakter van die mens word ook bepaal deur die twee vorste wat God oor die domeine gestel het. Die goeie engel lei die mens na heiligheid en 'n ewige lewe, maar die slegte engel lei die mens verder in sonde tot ' $n$ finale eskatologiese vernietiging. Sodoende kry die reddingsleer 'n sterk deterministiese kleur: alles lê vooraf in die Raad van God vasgevang. Die twee geeste tree op as "enticing, or seductive powers" 36 waarin die mens meegesleur word. "Der Mensch steht diesem gewaltigen Geschehen völlig passiv gegenüber" 37 .

In 1 QS $4: 25 v$ is die basis van die uitverkiesing dat God vooruit weet of die mens goeie en slegte dade sal verrig. In sy voorkennis van wat die mens eendag gaan doen, het God groter en kleiner dele van een van die twee geeste aan die mens gegee. Werke speel dus wel 'n kardinale rol in die soteriologie.

Burrows $^{38}$ sê dat die predestinasie in Qumran nie iets was waarop die gemeentelid sou roem nie. Dit is eerder die omgekeerde, naamlik dat hulle versekering dat hulle die ware openbaring van die wet en profete besit, met 'n intense gevoel van sondigheid gepaard gegaan het. In 1QS $11: 11$ is die uitverkiesing selfs 'n genadige versekering waarop die bidder hom kan beroep ten spyte van sy eie sondigheid. Sy uitverkiesing staan so vas dat menslike oortredings dit nie kan laat wankel nie, en dit roep die kwessie van genade na vore:

\subsection{Die rol van genade}

By Qumran ontbreek 'n verrekeningskema soos 'n loonaandeel teenoor 'n strafaandeel en bepalings waarvolgens mens loon sou kon verdien of straf ontvang. Die uitverkore groep ontvang alle heil, die ander alle verderf.

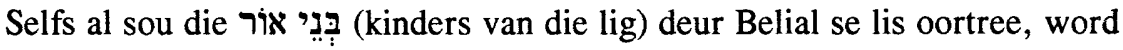
hulle gepredestineerde bestemming nie in gevaar gestel nie (1QS 3:22-24; $4: 20$ ).

Met ander woorde, "human frailty and inherited sin make man entirely dependent upon God's deliverance" ${ }^{39}$. Die gemeentelede het ten spyte van hulle streng wetsvervulling steeds hulleself slegs as בשר (vlees) 
gesien wat nie anders kan nie as om te sondig40. Hierdie swak vlees van die mens is self geneig tot sonde en is verder ook oop vir beïnvloeding deur slegte geeste. Waar die Ou-Testamentiese volk hulleself as (regverdig) sou beskryf, is die Qumran mensbeeld baie negatiewer en word dié woord by Qumran van God gebruik. In hierdie situasie beroep die gemeentelid hom op "God se geregtigheid" wat beteken dat God die sonde genadiglik bedek.

God se genade bestaan daarin dat Hy sy uitverkorenes help om by die gemeenskap aan te sluit deur hulle te voorsien van 'n kennis wat vir buitestaanders verborge is. Die gemeenskap self is gesien as 'n reddingsbron (communitas salus) vir diegene wat aansluit ${ }^{41}$, deurdat dit gehoorsaamheid fasiliteer. Binne die gemeenskap word redding bewerk deur kultiese versoeningsrites en die streng dissipline, maar hiermee, sê Becker ${ }^{42}$, word die gedagte aan 'n sola gratia deurbreek, want daarmee "wird das Heil doch wieder an Bedingungen geknüpft, die der Mensch zu erfüllen hat".

Ten spyte van die strenge wetsonderhouding sondig mense in die gemeenskap en hulle ontvang genade. Dit lyk of 'n nederige gesindheid van die enkeling waarin hy berou het (1QS 1:24b-26) en hom gehoorsaam onderwerp aan God (by implikasie aan al die bepalings van die gemeenskap), die deurslaggewende rol speel. God is diegene genadig wat ernstig daarna strewe om heilig voor Hom te leef. Lidmaatskap van die regte gemeenskap en hulle kultus bied versoening.

\subsection{Die rol van werke}

Beide die Qumrangemeenskap (wat hulleself as die mag van die lig sien) en die mag van die duisternis se eienskappe is gegrond (1QS 3:25) op hul onderskeie werke. 'n Voorwaarde geld vir diegene wat tot die gemeenskap toetree: hulle lewenswandel moet onberispelik wees; hulle moet met hart en siel hulle daaraan toewy en gehoorsaam buig onder die gesag van die wet en die dissipline van die gemeenskap. Volgens sy prestasie word die nuweling in 'n rangsisteem ingeskryf (1QS 2:19-24); hulle betig mekaar, en studeer voortdurend in die wet (5:25-6:8). 'n Man met insig (1QS 9:1226) het in besonder die taak om die gemeenskap in die wet te onderrig. Die gemeenskap waak dus daaroor dat hulle lewe ooreenstem met die eienskappe van die kinders van die lig.

Die groot probleem is die verhouding tussen wet en genade. Die meeste Qumrannavorsers sou erken dat "das Gesetz nicht Übermittler der צדקה ist"43 maar, dat die wet 'n sine qua non is, kan ook nie ontken word nie. 
Sanders se standpunt oor werke is: “obedience maintains one's position in the covenant, but it does not earn God's grace as such" ${ }^{44}$. Dit is korrek in die lig van ons bespreking van die predestinasie en genade, maar die objek van versoening in 1QS word telkens afgegrens om slegs diegene wat die wet onderhou, in te sluit. Die gemeenskap is uitverkies op grond van vooruitgesiene werke. In 1 QS 2:25-3:11 is dit slegs diegene wat die verbond perfek onderhou aan wie toegang tot die verbond verleen word. Ook so in CD 20 en 14:1b-2 is die objek van redding iemand wat die wet onderhou. Die wet is ook 'n toelatingsvereiste om in die verbond opgeneem te word en daarom lyk dit of die wet 'n groter rol speel as om bloot die lid in die genadekring te hou.

Die mens tree op in ooreenstemming met die gees wat sonder keuse aan hom toegeken is. Die dade van die mens is 'n gestalte van gehoorsaamheid aan die vors van die magskring, sodat "Im Tun geschiet und herrscht Frevel und Wahrheit" 45 . Die wet bly die norm van God se wil wat nagevolg moet word.

Die verband tussen genade en wet is moontlik soos volg: In sy swakheid kan die mens geensins uit homself volkome wandel nie. Hy is maar net blote vlees (בשר) maar, aangesien God vasgelê het wie Hy 'n volkome lewenswandel gaan bied, kan so 'n gepredestineerde mens nou in sy werke sy gepredestineerde gawe uitleef. Die gemeenskap sien hulleself as die skare van uitverkorenes, en kan dus hulle volkome wetsonderhouding "nur als Gabe Gottes ansehen, aber nicht als vollbrachte Leistung, die vor Gott dem Menschen erst einen guten Stand verschafft. Der Essener braucht sich nicht erst vor Gott Verdienste zu erwerben, sondern er ist schon kraft der prädestinatianischen Setzung Gottes im Heilsstand"46.

Die gemeenskap se eie versoeningswerke ry die gedagte aan sola gratia egter in die wiele, omdat dit die gedagte aan 'n eie plig na vore bring, en "weiter wird ja vor allem nicht vom Gesetz befreit, sondern gerade zur peinlich genauen kasuistischen, strengen Einzelerfüllung des Gesetzes verpflichte. Wird dieses Tun auch nicht als $\mathrm{zu}$ belohnende Leistung verstanden, so ist es doch für die Erhaltung des Heilszustandes eine conditio sine qua non" 47 .

Veral die verbondsluiting noop mens om die wet as toelatingsvereiste vir heil te sien. 1QS 5:1-20, en 1 QS 3:1-11 vereis van die nuwe verbondslid om 'n bindende eed te neem om "met sy hele hart en sy hele siel terug te keer na die wet van Moses volgens alles wat hy beveel het" (5:8b-9). Dan kan mens redding saamvat en sê: dit is nie op grond van die prestasie van wetsonderhouding dat mens in die Qumrandenke gered word nie, maar diegene wat die verbond (=wet) hou word deur God se genade 
gered. Met die wet verdien hulle nie guns voor God nie, maar skaar hulle by die "kinders van die lig". Die verbond kom daarin tot uiting dat God 'n God sal wees vir sy uitverkorenes en hulle verbondsplig is om die wet te gehoorsaam. Diegene wat die wet verwerp, verwerp die verbondsbepalings en sodoende die kader waarin redding plaasvind. Redding hang saam daarmee dat die "verbondskontrak" van die mens gehoorsaamheid vereis om reg te leef, en miskien is die moderne woord "sinergisme" die beste term om die Qumran-siening mee te tipeer. Die mens moet sy kant bring om gered te word: "For all men there was one way of salvation, depending on his own will and the mercy of God. If he would but apply himself to the study of God's Word in humility and pious devotion, God would answer by granting him a restored cleanliness, a sense of perfection" 48 .

\subsection{Die geheime kennis, gehoorsaamheid en afsondering}

La Sor ${ }^{49}$ sê dat die "secret knowledge almost always has to do with the salvation of Qumranians in the end-time". Hierdie bonatuurlike kennis is nie 'n intellektuele staat nie, maar 'n hemelse openbaring.

Twee tipes kennis is nodig vir redding: 1) die kennis van God se reddende weë wat die gemeentelid sal aanmoedig om vergifnis te vra, en 2) kennis van sy wil. Dit impliseer die hele gedagte van gehoorsaamheid. Die leraar van geregtigheid se interpretasie van die wet is getrou gehoorsaam. "Knowledge and trust were intended to issue in obedience, which is seen as a sine qua non for salvation" 50 . Hierdie gehoorsaamheid, vertroue en kennis is as 'n produk van God se werk in die hart van die mens beskou.

\section{6 $\quad$ Eskatologie: die stryd}

Die twee geeste loop nie parallel aan mekaar nie. Die mag van die duisternis bring die kinders van die lig voortdurend in versoeking om te struikel en hulle so na die mag van die sondiges oor te haal. Alhoewel God die vors van die duisternis toelaat om te bly heers, is Belial se mag begrens en God staan die kinders van die lig by deur die engel Migael (1QS 3:24). God se heilsdaad bestaan daarin om die mens in die eindgerig daarvan te verlos. Die hele Qumranteologie word oorskadu deur 'n nabye oordeelsverwagting.

Redding vind plaas op 'n oordeelsdag in die (nabye) toekoms, wanneer die een magsfeer in 'n geweldige oorlog vernietig sal word en sy aanhangers veroordeel word. By daardie geleentheid sal 'n heilstyd aanbreek wanneer die "kinders van die lig" aardse en hiernamaalse seën 
sal ervaar. Hulle oortredinge sal gereinig word en daarna sal God onreg op aarde vernietig sodat slegs die goeie bly voortbestaan (1QS 4:19-23). Die mens se verbondenheid aan die korrekte domein is die groot bepalende faktor vir redding. Die reddingsgedagte kry 'n kosmiese geladenheid deur die leer van die twee geeste. Die twee geeste vind hulle eindpunt in die dag van verrekening wanneer waarheid op aarde sal verskyn, en diegene wat aan God se gebooie vasgehou het, die seën van 'n lang lewe sal ervaar. Hierdie kosmiese beeld dring deur na die konkrete deurdat die gemeenskap as 'n vervanging (in hulle terme 'n "oorblyfsel") van Israel funksioneer (CD 2:11), en die objek van God se reddingshandelinge is. Wie hom van Israel afsonder en tot die gemeenskap toetree, word gered. Die eskatologiese en die hede word so vermeng dat eindtydelike heil tesame met meer alledaagse seën genoem word, byvoorbeeld in 1QS 4:20-23.

\subsection{Inhoud van die heil}

Die Ou-Testamentiese Godsvolk het heil onder andere sosiaal-polities gesien, om volksgeluk te hê. Qumran is meer konkreet: Heil lê materieel in 'n groot nageslag, eer, genesing, 'n lang lewe, bewaring, insig en heerskappy (1QS $2: 3 ; 4: 7,8$; CD 20:33v), maar soms is daar ook eskatologiese trekke, soos ewige vrede en die heerlikheid van Adam ${ }^{51}$.

Soms word die hele orde, as 'n mens van so-iets kan praat, omgekeer: sake wat andersins as heilbringend beskou is, word ook heilstoesegginge, byvoorbeeld om deel te hê aan die lot van die heiliges (1QS 11:7bv) en teenoor die kennis hierbo bespreek, is kennis ook 'n heilsgoed (1QS 2:3v 4:22, 11:7). "Life in the community is sometimes viewed as an end of salvation, a sort of heaven upon earth" 52 . Uiteraard is al die heilstoesegginge simbole van die een groot heil om naby God te wees en sy guns te ervaar (1QS 11:13-15, CD 20:34).

\section{8 'n Messias}

Al is die leraar van geregtigheid in Qumran die "greatest personality of later Judaism known to us" 53 , ontbreek 'n messias wat 'n reddende rol speel deur op een of ander wyse versoening te doen vir sy mense in 1QS. Hierin moet die grootste verskil met Paulus gevind word, want Paulus se Damaskuservaring het sy teologie merkbaar anders gemaak as dié van enige ander Joodse skrywer. 
Omdat die rol van werke steeds in Qumran gehandhaaf word, is dit geregverdig om saam met Garnet ${ }^{54}$ te sê dat die term "redding deur die werke van die wet" wel betekenis in Nuwe-Testamentiese Judaïsme sou hê. Ten spyte van die groot klem op genade, die verbond en uitverkiesing was gehoorsaamheid steeds noodsaaklik as voorvereiste vir redding van die enkeling en die gemeenskap.

Die Qumranwerke dra nie die gedagte van "personally piled up merits" nie en daarom sou mens die "tradisionele" gedagte dat Jode uit verdienste van hulle werke gered is, nie op grond van Qumran kon ondersteun nie. Sanders se kritiek op hierdie siening van Judaïsme was 'n sinvolle bydrae. Die gevoel is egter dat Sanders te min gemaak het daarvan dat die wet in Qumran 'n wesenlike rol bly speel naas genade.

'n Debat met Sanders kan egter nie op so 'n beperkte ondersoek gegrond word nie, maar die verskille tussen hierdie ondersoek en die standpunte van Sanders en Eisenman noodsaak 'n projek wat die hele Qumran-corpus sal insluit.

\section{NOTAS:}

Hierdie artikel is 'n effens gewysigde samevatting van J W Semmelink, Die reddingsgedagte in die Qumran manuskripte $1 Q S$ en 1QpHab. BD-Skripsie, Universiteit van Pretoria, 1992 onder leiding van Prof A B du Toit. Die werkswyse en die standpunte wat destyds gestel is, word behou. In 'n beplande opvolgstudie sal egter 'n ander werkswyse gevolg word.

M Burrows, The Dead Sea Scrolls, New York 1955, 334.

E P Sanders, Paul and Palestinian Judaism, Philadelphia 1977, 320. Kursiewe druk is dié van Sanders.

A B Du Toit, "Gesetzesgerechtigkeit und Glaubensgerechtigkeit in Rom 4:13-25: Im Gespräch mit E P Sanders” HTS 44(1988), 71-80.

R Eisenman \& M Wise, The Dead Sea Scrolls uncovered, Brisbane 1992. Die skripsie waarvan hierdie artikel 'n samevatting is, is voltooi voordat Qumran deur publikasies soos dié van Eisenman en Wise of B Thiering, Jesus the man, London 1992 ter plaatse bekend geword het. 'n Derde publikasie in hierdie verband is dié van M Biagent \& $\mathrm{R}$ Leigh The Dead Sea Scrolls deception, London 1991. 'n Veel groter ondersoekveld is deur hierdie publikasies oopgegooi. 
Die teksuitgawe wat gebruik is, is dié van E Lohse, Die texte aus Qumran, München 1971.

M Black, The scrolls and Christian origins, New York 1961, 124.

$\mathrm{P}$ Wernberg-Møller, The manual of discipline translated and annotated with an introduction, vol 1 van Studies on the texts of the desert of Judea ed J v d Ploeg, Michigan 1957, 45.

$10 \quad$ Vergelyk Deuternomium 27:16-26.

11 W H Brownlee, "Anthropology and soteriology in the dead sea scrolls and in the New Testament", in The use of the Old Testament in the New and other essays, Durham. 1972, 231.

12 A R G Deasley, "The Holy Spirit in the Dead Sea Scrolls", Wesleyan Theological Journal 21 (1986), 45-73. Vergelyk veral p 50.

13 J Becker, Das Heil Gottes (Studien zur Umwelt des Neuen Testaments), Göttingen 1964, 84. Hy gebruik die term "Lehrunterweisung".

14 Vir 'n bespreking van hierdie siening, vergelyk Wernberg-Møller, $a w$, $1957,70$.

$15 \quad$ Deasley, $a w, 52$.

$16 \quad$ Brownlee, $a w, 124$.

17 Die "horoskope" (4QS 186) is reeds aangehaal by die bespreking van 3:20, waar ook van groter en kleiner aandele in die twee geeste sprake is.

Wernberg-Møller, $a w, 1957,93$ nota 26.

P Garnet, Salvation and atonement in the Qumran Scrolls, Tübingen 1977, 98.

Wernberg-Møller, $a w, 1957,93$ nota 26.

W S La Sor, The Dead Sea Scrolls and the New Testament, Grand Rapids 1972, 88.

W S La Sor, $a w, \mathrm{~J}$ V Chamberlain, "Toward a Qumran soteriology", Novum Testamentum 3 (1959), 305-313; vergelyk veral 309.

Chamberlain, $a w, 306$. Die raad van vyftien word ook deur WernbergMøller, $a w, 1957,122$ nota 1 en 123 nota 3 asook deur Garnet, $a w, 1977$, 55 bespreek. 
G Vermes, The Dead Sea Scrolls in English, London 1987, 72.

25 K G Kuhn, "Die beiden Messias Aarons und Israels”, New Testament Studies 1 (1955), 168-179; veral 178.

26 Burrows, $a w, 1955,334$.

$27 \quad$ Lohse, $a w, 1971$, eindnota 83.

28 L Koehler, \& W Baumgartner, Lexicon in veteris testamenti libros, Leiden 1958, 794.

29 G von Rad, Old Testament Theology Volume 1, London 1975, 370.

$30 \quad$ Becker, $a w, 1964,112$.

$31 \quad$ Burrows, $a w, 1955,257$.

$32 \quad$ La Sor, $a w, 1972,87$.

$33 \quad$ Von Rad, $a w, 1975,195$.

$34 \quad$ Von Rad, $a w, 193$.

35 W D Davies, "Paul and the Dead Sea Scrolls: Flesh and Spirit", in: K Stendahl (ed), The Scrolls and the New Testament, Westport 1975, 157-182.

$36 \quad$ Brownlee, $a w, 213$.

37 S Schulz, "Zur Rechtfertigung aus Gnaden in Qumran und bei Paulus", Zeitschrift für Theologie und Kirche 56 (1959), 157.

Burrows, $a w, 1955,263 \mathrm{v}$.

39 Brownlee, $a w, 225$.

$40 \quad$ Vergelyk 1QS 11:9-11 en Schulz, $a w, 160$.

$41 \quad$ Garnet, $a w, 1977,117$.

$42 \quad$ Becker, $a w, 125$.

$43 \quad$ Becker, $a w, 116$.

$44 \quad$ Sanders, $a w, 420$. 
45 Becker, $a w, 90$. Die klem is dié van Becker. Vergelyk ook Becker, $a w, 87$.

$46 \quad$ Becker, $a w, 118$.

$47 \quad$ Becker, $a w, 125$.

$48 \quad$ J M Allegro, The Dead Sea Scrolls, London 1956, 126.

$49 \quad$ La Sor, $a w, 92$.

$50 \quad$ Garnet, $a w, 116$.

51 1QS 2:4 en CD 3:19v. Vergelyk ook Garnet, $a w, 114$.

52 Garnet, $a w, 21$.

53 W Grundmann, "The Teacher of Righteousness of Qumran and the question of justification by faith in the theology of the Apostle Paul", in: J MurphyO'Connor (ed), Paul and the Dead Sea Scrolls, New York 1990, 85-114. 'n Verwerking van 'n artikel wat in 1960 in Revue de Qumran verskyn het.

54 P Garnet, "Qumran light on Pauline soteriology" in: D A Hagner \& M J Harris (eds), Pauline Studies. Essays presented to Professor F F Bruce on his 70th birthday. Grand Rapids 1980, 22. 